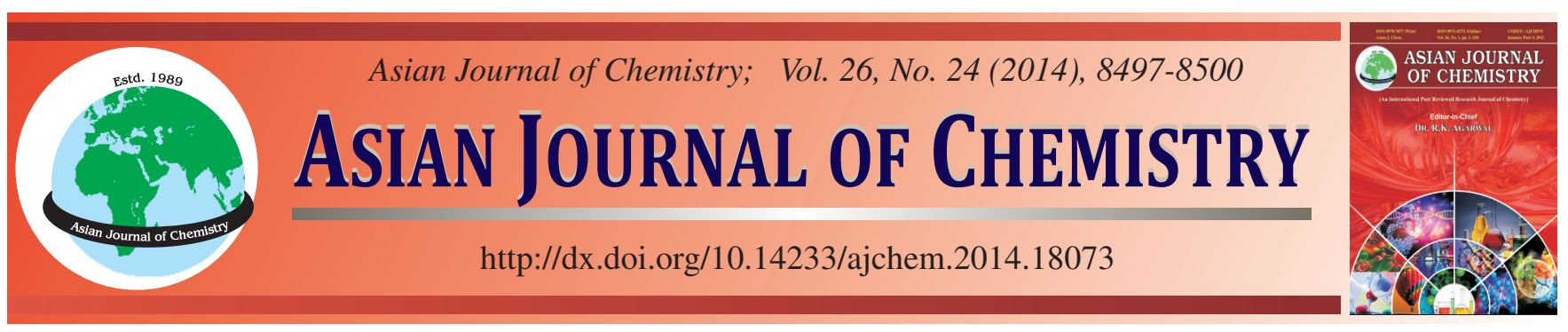

\title{
Design, Synthesis, X-Ray Crystallographic Study and Anticancer Activity of Novel 4-(7-Chloro-1-methylquinolin-4-(1H)-ylideneamino)-phenyl-3-(dimethylamino)-prop-2-en-1-one
}

\author{
Mostafa M. Ghorab ${ }^{1, *}$, Mansour S. Alsaid ${ }^{1}$, Hazem A. Ghabbour ${ }^{2}$ and Hoong-Kun Fun ${ }^{2}$
}

${ }^{1}$ Department of Pharmacognosy, College of Pharmacy, King Saud University, P.O. Box 2457, Riyadh 11451, Kingdom of Saudi Arabia ${ }^{2}$ Department of Pharmaceutical Chemistry, College of Pharmacy, King Saud University, P.O. Box 2457, Riyadh 11451, Saudi Arabia

*Corresponding author: Fax: +966 1 4670560; Tel: +966 534292860; E-mail: mmsghorab@yahoo.com

\begin{abstract}
The disease of cancer has been ranked second after cardiovascular diseases and plant-derived molecules have played an important role for the treatment of cancer. On the account of the reported anticancer activity of quinolines containing the different biologically active moieties, a novel 4-[7-chloro-1-methylquinolin-4- $(1 H)$-ylideneamino]-phenyl-3-(dimethylamino)-prop-2-en-1-one (3) was synthesized using 1-[4-(7-chloroquinolin-4-ylamino)phenyl]ethanone (2) as strategic starting material. Compound $\mathbf{3}$ was obtained in good yield via reaction of 1-[4-(7-chloroquinolin-4-ylamino)phenyl]ethanone (2) with DMF-DMA in dry toluene. The structure of the newly synthesized compound was confirmed on the basis of elemental analysis, IR, ${ }^{1} \mathrm{H} N \mathrm{NR},{ }^{13} \mathrm{C}$ NMR spectra and X-ray crystallographic analysis. Cytotoxic activity of the newly synthesized compound $\mathbf{3}$ was evaluated against human breast cancer cell line (MCF7). It was found that compound $\mathbf{3}$ is nearly as active as the reference drug (doxorubicin).
\end{abstract}

Keywords: Novel quinoline, X-Ray crystallographic study, Cytotoxic activity.

\section{INTRODUCTION}

Cancer is a multifaceted disease that represents one of the leading causes of mortality in developed countries. Worldwide, one in eight deaths is due to cancer and it is the second most common cause of death in the US, exceeded only by heart disease ${ }^{1}$ Chemotherapy is the mainstay for cancer treatment, the use of available chemotherapeutics is often limited due to undesirable side effects. It is important to identify new agents and new targets for the treatment of cancer. Nitrogen heterocycles have received a great deal of attention in the literature due to their role as active pharmacophores of historical significance. Among these heterocyclic systems, especially those containing pyridine rings are associated with diverse pharmacological properties such as anticancer ${ }^{2,3}$, antimicrobial $^{4-6}$, anticonvulsant ${ }^{7}$, antiviral ${ }^{8}$ anti-HlV ${ }^{9}$, antifungal and antimycobacterial activities ${ }^{10}$. Recently considerable attention has been devoted to the construction of new derivatives of quinoline on the account of their reported biological activities ${ }^{11-18}$. From the literature survey, several methods have been described for the elaboration of substituted quinolines ${ }^{19-}$ ${ }^{21}$, which as a class have been reported to have anticancer and antileukemic activity. Different mechanisms account for the cytotoxic effect of this class of compounds, the most prominent mechanism was the inhibition of carbonic anhydrase isozymes
(CA). Cancer is a top killer of human beings. Thus there is a great urgency to develop highly efficacious and minimally toxic treatments for cancer. Although tremendous progress has been achieved in the development of novel cancer treatments. Most of the current cancer drugs usually exhibit high toxicity and are severely resisted by tumor cells in the clinic. This dilemma is particularly true for DNA-damaging agents, the mainstay of cancer treatment ${ }^{22}$. Quinolines were found to possess several pharmacological properties, including anticancer activity ${ }^{23-27}$. Also, a large number of structurally novel quinolines have ultimately been reported to show substantial anticancer activity in vitro and in vivo ${ }^{28}$. Based on the above information and as a continuation of a previous work on anticancer agents ${ }^{29-36}$, we report the synthesis, X-ray crystallographic studies and anti-breast cancer activity of some novel quinoline derivative.

\section{EXPERIMENTAL}

The starting material 4,7-dichloroquinoline (1) was purchased from Sigma-Aldrich. Melting points were determined on an electrothermal melting point apparatus (Stuart Scientific, Stone) and were uncorrected. Precoated Silica gel plates (Kiesel gel $0.25 \mathrm{~mm}, 60 \mathrm{~F} 254$, Merck) were used for thin layer chromatography (TLC). The developing solvent system was 
chloroform/methanol (10: 3 ) and the spot were detected by ultraviolet light. Infrared spectra (KBr disc) were recorded on FT-IR spectrophotometer (Perkin Elmer) at the Research Center, College of Pharmacy, King Saud University, Saudi Arabia. ${ }^{1} \mathrm{H}$ NMR spectra were scanned in dimethylsulfoxide (DMSO- $d_{6}$ ) on a NMR spectrophotometer (Bruker AXS Inc.) operating at $500 \mathrm{MHz}$ for ${ }^{1} \mathrm{H}$ and $125.76 \mathrm{MHz}$ for ${ }^{13} \mathrm{C}$ at the aforementioned Research Center. Chemical shifts are expressed in $\delta$ values (ppm) relative to tetramethylsilane (TMS) as an internal standard. Exchangeable protons were confirmed by addition of drop of $\mathrm{D}_{2} \mathrm{O}$. Elemental analyses were done on a model 2400 CHNSO analyzer (Perkin Elmer). The X-ray measurement of compound $\mathbf{3}$ was performed using Bruker SMART APEXII CCD diffractometer ${ }^{37,38}$. Crystallographic data of compound $\mathbf{3}$ has been deposited with the Cambridge Crystallographic Data Center (supplementary publication numbers CCDC-923085). Copy of the data may be obtained free of charge from the Director, CCDC, 12 Union Road, Cambridge, CB2 1EZ, UK (deposit@ccdc.cam.ac.uk).

X-Ray crystallography: Single crystal suitable for Xray diffraction was mounted on glass fibres. The diffraction data were collected on Bruker APEX-II CCD area-detector diffract-tometer with $\mathrm{CuK}_{\alpha}$ radiation $(\lambda=1.54178 \AA$ ) at a temperature of 296(2) K. The data for this compound was processed with SAINT and corrected for absorption using multi-scan ${ }^{39}$. The structures were solved by direct methods using the program SHELXTL97 $7^{40}$ and refined by full-matrix least squares technique on $\mathrm{F}^{2}$ using anisotropic displacement parameters using SHELXTL ${ }^{40}$ program. All geometrical calculations were carried out using the program PLATON ${ }^{41}$. Molecular graphics were drawn using SHELXTL ${ }^{40}$ and PLATON ${ }^{41}$ program. All the hydrogen atoms were fixed at calculated positions with a common isotropic displacement parameters set to 1.2 (1.5 for methyl groups) times the equivalent isotropic $\mathrm{U}$ values of the parent carbon atoms. A rotating group model was applied to the methyl groups. The crystallographic data are given in Table-1. Hydrogen bonding interactions are shown in Table-2. The selected bond lengths and bond angles are listed in Table-3. The scheme of the synthesis of the compound is shown in Scheme-I.

Synthesis of 1-(4-(7-chloroquinolin-4-ylamino)phenyl)ethanone (2): This compound was synthesized according the reported method ${ }^{42}$.

Synthesis of 4-(7-chloro-1-methylquinolin-4(1H)-ylideneamino)phenyl-3-(dimethylamino)-prop-2-en-1-one (3): A mixture of 1-(4-(7-chloroquinolin-4-ylamino)-phenyl)ethanone (2) (2.97 g, $0.01 \mathrm{~mol})$ and dimethylformamide-dimethylacetal $(1.19 \mathrm{~g}, 0.01 \mathrm{~mol})$ in dry toluene $(30 \mathrm{~mL})$ was refluxed for $10 \mathrm{~h}$. The reaction mixture was cooled and the obtained solid was recrystallized from ethanol to give 3. Yield $89 \%$; m.p. $268.1{ }^{\circ} \mathrm{C}$; IR $\left(\mathrm{KBr}, v_{\max }, \mathrm{cm}^{-1}\right): 3100(\mathrm{CH}$ arom.), 2966, 2856 (CH aliph.), $1696(\mathrm{C}=\mathrm{O}), 1618(\mathrm{C}=\mathrm{N}), 776(\mathrm{C}-\mathrm{Cl}) .{ }^{1} \mathrm{H}$ NMR spectrum in ( DMSO- $\left.d_{6}\right): 2.4\left[\mathrm{~s}, 3 \mathrm{H}, \mathrm{N}\left(\mathrm{CH}_{3}\right)_{2}\right] 2.9[\mathrm{~s}$, $\left.3 \mathrm{H}, \mathrm{N}-\mathrm{CH}_{3}\right], 5.4,6.5[2 \mathrm{~d}, 2 \mathrm{H}, \mathrm{CH}=\mathrm{CH}$ quinoline, $J=7.1,7.3$ $\mathrm{Hz}], 6.1,7.4$ [2d, 2H, CH=CH, $J=7.5,7.4 \mathrm{~Hz}], 6.9-7.6$ $[\mathrm{m}, 3 \mathrm{H}, \mathrm{Ar}-\mathrm{H}] .{ }^{13} \mathrm{C}$ NMR spectrum of $\mathbf{3}$ in ( DMSO- $\left.d_{6}\right): 36.3$, 44.5(2), 91.5, 114.6, 115.3, 116.9, 121.4(2), 131.7, 132.8(2), 133.0, 135.9, 136.6, 141.4, 146.2, 152.5, 161.4, 166.4,191.3. Anal. Calcd for $\mathrm{C}_{21} \mathrm{H}_{20} \mathrm{~N}_{3} \mathrm{OCl}$ (365.86): C, 68.94; H, 5.51; N,
11.49; found: C, 68.66; H, 5.22; N, 11.74. Crystals suitable for X-ray diffraction was obtained after a week on slow evaporation of the solution ${ }^{43}$.

in vitro Cytotoxic activity: The human tumor breast cancer cell line (MCF7) was obtained from the National Cancer Institute, Cairo, Egypt. The cytotoxic activity of the synthesized compound was measured by the Sulfo-Rhodamine-B stain (SRB) assay as reported by Skehan et al..$^{44}$. Cells were plated in 96-multiwell plate $\left(10^{4}\right.$ cells per well) for $24 \mathrm{~h}$ before treatment with the compounds to allow attachment of cell to the wall of the plate. Tested compounds were dissolved in DMSO and diluted with saline. Different concentrations of the compounds under test $\left(5,12.5,25\right.$ and $\left.40 \mu \mathrm{mol} \mathrm{L}^{-1}\right)$ were added to the cell monolayer. Triplicate wells were prepared for each individual dose. Monolayer cells were incubated with the compounds for $48 \mathrm{~h}$ at $37{ }^{\circ} \mathrm{C}$ and in atmosphere of $5 \% \mathrm{CO}_{2}$. After $48 \mathrm{~h}$, cells were fixed, washed and stained for $0.5 \mathrm{~h}$. with $0.4 \%(\mathrm{~m} / \mathrm{v})$ SRB dissolved in $1 \%$ acetic acid. Unbounded dye was removed by four washes with $1 \%$ acetic acid and attached stain was recovered with tris-EDTA buffer. Colour intensity was measured in an ELISA reader (sunostick medical technology, SPR-960B, U.K.). Negative control was added by using the cell lines with the solvent without drug. The relation between surviving fraction and drug concentration was plotted to get the survival curve of each tumor cell line after the specified time. The concentration required for $50 \%$ inhibition of cell viability $\left(\mathrm{IC}_{50}\right)$ was calculated and compared with the reference drug doxorubicin and the results are given in Table-3.

\section{RESULTS AND DISCUSSION}

The present work was to design, synthesis, X-ray crystallographic study and antibreast cancer activity of novel 4-(7chloro-1-methylquinolin-4-(1H)-ylide-neamino)-phenyl)-3(dimethylamino)-prop-2-en-1-one (3) (Scheme-I). Interaction of 4-(7-chloro-1-methylquinolin-4-(1H)-ylideneamino)phenyl-ethanone $(\mathbf{2})^{42}$ with dimethylformamide-dimethylacetal in dry toluene yielded the corresponding 4-(7-chloro-1-methylquinolin-4-(1H)-ylideneamino)-phenyl)-3-(dimethyl)-prop-2en-one (3) in good yield. The structure of compound $\mathbf{3}$ was proved on the basis of elemental analysis, IR, ${ }^{1} \mathrm{H}$ NMR, ${ }^{13} \mathrm{C}$ NMR and $\mathrm{x}$-ray analysis. The IR spectrum of $\mathbf{3}$ showed bands at $3100 \mathrm{~cm}^{-1}$ (CH aromatic), 2966, $2856 \mathrm{~cm}^{-1}$ (CH aliphatic), $1696 \mathrm{~cm}^{-1}(\mathrm{C}=\mathrm{O}), 776 \mathrm{~cm}^{-1}(\mathrm{C}-\mathrm{Cl})$. Also, ${ }^{1} \mathrm{H}$ NMR spectrum in $\left(\mathrm{DMSO}-d_{6}\right)$ indicated the presence of a singlet at $2.4 \mathrm{ppm}$ which could be assigned to $\mathrm{N}\left(\mathrm{CH}_{3}\right)_{2}$ groups, $2.9 \mathrm{ppm}$ due to $\mathrm{N}-\mathrm{CH}_{3}$ group, 5.4, 6.5 two duplets for $\mathrm{CH}=\mathrm{CH}$ groups of quinoline ring and 6.1, 7.4 two duplets for $\mathrm{CO}-\mathrm{CH}=\mathrm{CH}$ group. ${ }^{13} \mathrm{C}$ NMR spectrum of $\mathbf{3}$ in (DMSO- $d_{6}$ ) exhibited signals at $36.3,44.5(2), 91.5,114.6,115.3,116.9,121.4(2), 131.7$, $132.8(2), 133.0,135.9,136.6,141.4,146.2,152.5,161.4$, 166.4, 191.3.

Crystal structure description of compound (3): Slow evaporation of the pure compound $\mathbf{3}$ from ethanol yielded its single crystal. Single crystal of suitable size was selected for $\mathrm{X}$-ray diffraction analysis. Data was collected on a Bruker APEX-II CCD area diffractometer equipped with graphite monochromatic $\mathrm{CuK}_{\alpha}$ radiation $(\lambda=1.54178 \AA)$ at $296 \mathrm{~K}$. 
<smiles>Clc1ccc2c(Cl)ccnc2c1</smiles>

( 1 )
(2)<smiles>CN(C)/C=C/C(=O)c1ccc(/N=c2\ccn(C)c3cc(Cl)ccc23)cc1</smiles>

(3)

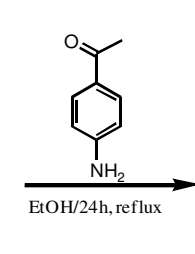<smiles>CC(=O)c1ccc(Nc2ccnc3cc(Cl)ccc23)cc1</smiles>

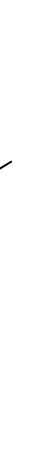

Seheme-I: Formation of novel quinoline derivative $\mathbf{3}$

Cell refinement and data reduction were done by Bruker SAINT; program used to solve structure and refine structure is SHELXTL. The final refinement was performed by fullmatrix least-squares techniques with anisotropic thermal data for non-hydrogen atoms on $\mathrm{F}^{2}$. All the hydrogen atoms were placed in calculated positions and constrained to ride on their parent atoms. Multi-scan absorption correction was applied by use of SADABS software. The crystallographic data and refinement information are summarized in Table-1.

\begin{tabular}{|c|c|}
\hline \multicolumn{2}{|c|}{$\begin{array}{c}\text { TABLE-1 } \\
\text { CRYSTALLOGRAPHIC DATA OF COMPOUND } 3\end{array}$} \\
\hline Empirical formula & $\mathrm{C}_{21} \mathrm{H}_{20} \mathrm{~N}_{3} \mathrm{OCl}$ \\
\hline Formula weight & 365.85 \\
\hline Temperature $(\mathrm{K})$ & 296 \\
\hline Crystal system & Monoclinic \\
\hline Space group & $\mathrm{C} 2 / \mathrm{c}$ \\
\hline $\mathrm{CuK}_{\alpha}$ radiation, $\lambda$ & $1.54178 \AA$ \\
\hline a $(\AA)$ & $24.6582(6)$ \\
\hline b $(\AA)$ & $10.1905(2)$ \\
\hline$c(\AA)$ & $18.6459(5)$ \\
\hline$\alpha\left({ }^{\circ}\right)$ & 90.0 \\
\hline$\beta\left(\left(^{\circ}\right)\right.$ & $128.311(3)$ \\
\hline$\gamma\left({ }^{\circ}\right)$ & 90.0 \\
\hline $\mathrm{V}\left(\AA^{3}\right)$ & $3676.38(15)$ \\
\hline $\mathrm{Z}$ & 4 \\
\hline $\mathrm{F}(000)$ & 1536 \\
\hline$\theta$ Range for data collection $\left({ }^{\circ}\right)$ & $3.6-69.1$ \\
\hline$\mu\left(\mathrm{mm}^{-1}\right)$ & 1.95 \\
\hline Density (calc.) $\left(\mathrm{g} / \mathrm{cm}^{3}\right)$ & 1.322 \\
\hline Crystal shape and color & Block, brown \\
\hline Crystal size $\left(\mathrm{mm}^{3}\right)$ & $0.25 \times 0.24 \times 0.11$ \\
\hline $\mathrm{h} / \mathrm{k} / \mathrm{l}$ & $-30,27 /-12,12 /-18,22$ \\
\hline Measured reflections & 19443 \\
\hline Independent reflections & $3447\left[\mathrm{R}_{\mathrm{int}}=0.061\right]$ \\
\hline Reflections with $\mathrm{I}>2 \sigma(\mathrm{I})$ & 2878 \\
\hline Goodness-of-fit on $\mathrm{F}^{2}$ & 1.05 \\
\hline $\mathrm{R}\left[\mathrm{F}^{2}>2 \sigma\left(\mathrm{F}^{2}\right)\right]$ & 0.040 \\
\hline$w R\left(F^{2}\right)$ & 0.0 .113 \\
\hline$\Delta \rho_{\max }\left(\mathrm{e} \AA^{-3}\right)$ & 0.18 \\
\hline$\Delta \rho_{\min }\left(\mathrm{e} \AA^{-3}\right)$ & -0.25 \\
\hline
\end{tabular}

The crystal structure of the title compound 3 contains one molecule in the asymmetric unit. The labeled displacement ellipsoid plot of this molecule is shown in Fig. 1. The hydrogenbonding interactions are listed in Table-2. Fig. 2 depicts the packing of the molecules in the crystal structure.

\begin{tabular}{|c|c|c|c|c|}
\hline \multicolumn{5}{|c|}{$\begin{array}{c}\text { TABLE-2 } \\
\text { HYDROGEN-BOND GEOMETRY }\left(\AA{ }^{\circ}{ }^{\circ}\right)\end{array}$} \\
\hline $\mathrm{D}-\mathrm{H} \cdots \mathrm{A}$ & D-H & $\mathrm{H} \cdots \mathrm{A}$ & $\mathrm{D} \cdots \mathrm{A}$ & D-H $\cdots A$ \\
\hline 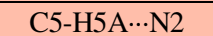 & 0.9300 & 2.5100 & $2.820(3)$ & 100.00 \\
\hline $\mathrm{C} 14-\mathrm{H} 14 \mathrm{~A} \cdots \mathrm{O} 1$ & 0.9300 & 2.4100 & $2.735(3)$ & 100.00 \\
\hline $\mathrm{C} 18-\mathrm{H} 18 \mathrm{~A} \cdots \mathrm{O} 1$ & 0.9300 & 2.3600 & $2.744(3)$ & 104.00 \\
\hline $\mathrm{C} 21-\mathrm{H} 21 \mathrm{~A} \cdots \mathrm{O} 1 \mathrm{i}$ & 0.9600 & 2.4400 & $3.381(2)$ & 166.00 \\
\hline $\mathrm{C} 21-\mathrm{H} 21 \mathrm{C} \cdots \mathrm{O} 1 \mathrm{ii}$ & 0.9600 & 2.5300 & $3.335(3)$ & 142.00 \\
\hline \multicolumn{5}{|c|}{ Symmetry codes: (i) $-\mathrm{x},-\mathrm{y},-\mathrm{z}+1$; (ii) $\mathrm{x}+1 / 2,-\mathrm{y}+1 / 2, \mathrm{z}+1 / 2$} \\
\hline & & & & $-\int^{\mathrm{N} 3}$ \\
\hline
\end{tabular}

Fig. 1. ORTEP diagram of the title compound $\mathbf{3}$ drawn at $40 \%$ ellipsoids for non-hydrogen atoms

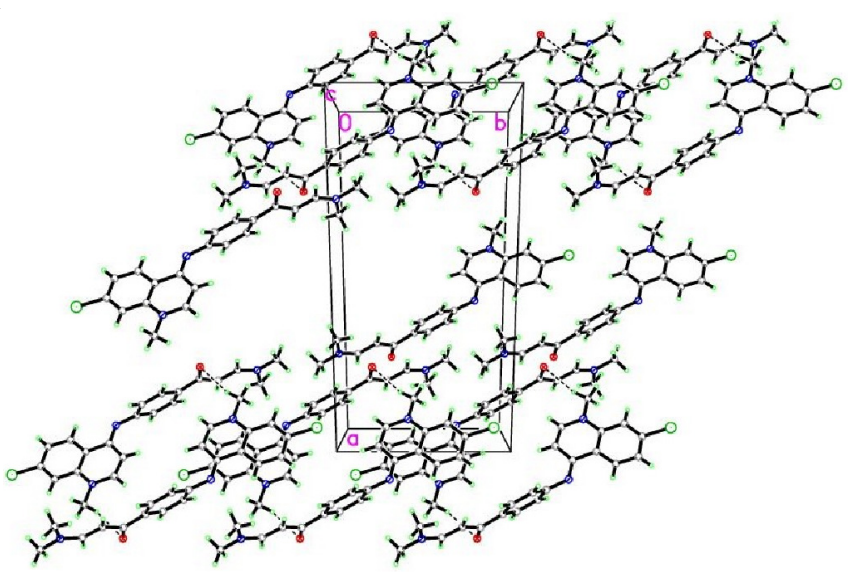

Fig. 2. Crystal packing of compound $\mathbf{3}$ showing the intermolecular hydrogen bonds

in vitro Antibreast cancer activity: The corresponding 4-(7-chloro-1-methylquinolin-4-(1H)-ylideneamino)phenyl-3(dimethylamino)-prop-2-en-1-one (3) was evaluated for their in vitro cytotoxic activity against human breast cancer cell line (MCF7). Doxorubicin which is one of the most effective anticancer agents was used as the reference drug in this study. The relationship between surviving fraction and drug concentration was plotted to obtain the survival curve of breast cancer cell line (MCF7). The response parameter calculated was the $\mathrm{IC}_{50}$ value, which corresponds to the concentration required for $50 \%$ inhibition of cell viability. Table- 3 shows the in vitro cytotoxic activity of the tested compound compared to the reference drug. It was found that, in the negative control, solvent has no effect on the cells as the surviving fraction is 1.00 , from this results it was found that the corresponding 4(7-chloro-1-methylquinolin-4-(1H)-ylideneamino)phenyl-3(dimethylamino)-prop-2-en-1-one $(3)$ with $\left(\mathrm{IC}_{50}=74.3 \mu \mathrm{M}\right)$ is nearly as active as the positive control (doxorubicin) with $\left(\mathrm{IC}_{50}=71.8 \mu \mathrm{M}\right)$. 


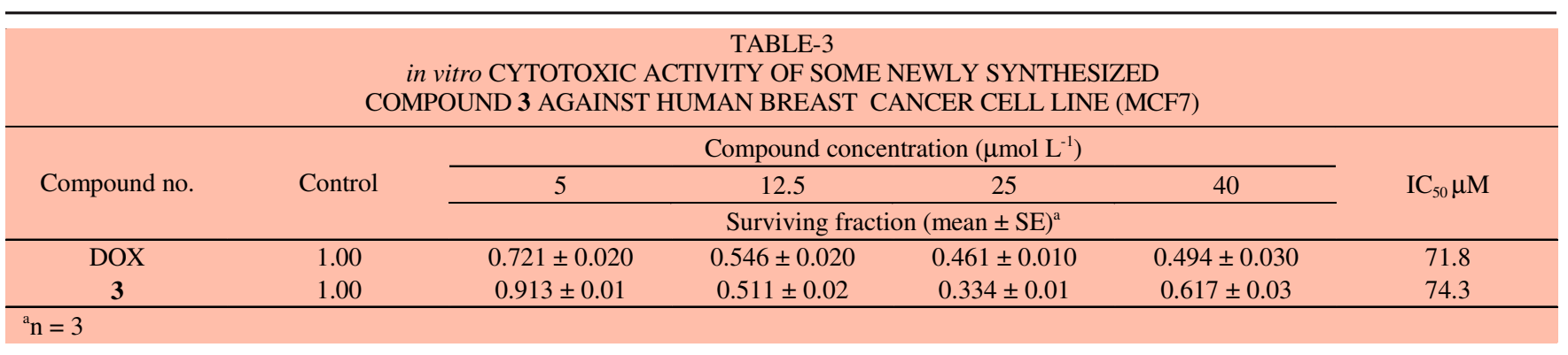

\section{Conclusion}

The novel synthesized 4-(7-chloro-1-methylquinolin-4(1H)-ylideneamino)phenyl-3-(dimethylamino)-prop-2-en-1one (3) has been spectroscopically characterized by FT-IR, ${ }^{1} \mathrm{H},{ }^{13} \mathrm{C}$ NMR and single crystal X-ray diffraction study. The structural elucidation is used to explore the conformation features of the compound $\mathbf{3}$. The synthesized compound adopt the envelope conformation. In the crystal packing, the molecule are linked together by $\mathrm{N}-\mathrm{H}$...O hydrogen bonds to form one dimensional chain. From the above results, it is concluded that administration of the tested compound on human breast (MCF7) cell line showed promising cytotoxic activity. Compound $\mathbf{3}$ with $\left(\mathrm{IC}_{50}=74.3 \mu \mathrm{M}\right)$ is nearly as active as the reference drug (Doxorubicin) with $\left(\mathrm{IC}_{50}=71.8 \mu \mathrm{M}\right)$.

\section{ACKNOWLEDGEMENTS}

The authors would like to extend their sincere appreciation to the Deanship of Scientific Research at King Saud University for funding of this research through the Research Group Project no. RGP-VPP-302.

\section{REFERENCES}

1. A. Jemal, R. Siegel, E. Ward, T. Murray, J.C.A. Xu and M.J. Thun, Cancer J. Clin., 57, 43 (2007).

2. A. Srivastava and S.N. Pandeya, Int. J. Curr. Pharm. Rev. Res., 1(3), 1 (2011).

3. M.S. Mohamed, Y.E. El-Deen, S.M. El-Hallouty and M. El-Araby, Open. J. Med. Chem., 2, 78 (2012).

4. N.B. Patel, S.N. Agravat and F.M. Shaikh, Med. Chem. Res., 20, 1033 (2011),

5. N.B. Patel and S.N. Agravat, Chem. Heterocycl. Comp., 45, 1343 (2009).

6. T. El-Emary and S. El-Mohsen, Molecules, 17, 14464 (2012).

7. E.G. Paronikyan, A.S. Noravyan, I.A. Dzhagatspanyan, I.M. Nazaryan and R.G. Paronikyan, Pharm. Chem. J., 36, 465 (2002).

8. A.M.R. Bernardino, A.R. De Azevedo, L.C.D. Pinheiro, J.C. Borges, V.L. Carvalho, M.D. Miranda, M.D.F. De Meneses, M. Nascimento, D. Ferreira, M.A. Rebello, V.A.G.G. Silva and I.C.P.P. de Frugulhetti, Med. Chem. Res., 16, 352 (2007).

9. T.J. Tucker, J.T. Sisko, R.M. Tynebor, T.M. Williams, P.J. Felock, J.A. Flynn, M. Lai, Y. Liang, G. McGaughey, M. Liu, M. Miller, G. Moyer, V. Munshi, R. Perlow-Poehnelt, S. Prasad, J.C. Reid, R. Sanchez, M. Torrent, J.P. Vacca, B.-L. Wan and Y. Yan, J. Med. Chem., 51, 6503 (2008).

10. M.G. Mamolo, D. Zampieri, V. Falagiani, L. Vio, M. Fermeglia, M. Ferrone, S. Pricl, E. Banfi and G. Scialino, ARKIVOC, 231 (2003).

11. P. Nasveld and S. Kitchener, Trans. R. Soc. Trop. Med. Hyg., 99, 2 (2005).

12. P.A. Leatham, H.A. Bird, V. Wright, D. Seymour and A. Gordon, Eur. J. Rheumatol. Inflamm., 6, 209 (1983).

13. W.A. Denny, W.R. Wilson, D.C. Ware, G.J. Atwell, J.B. Milbank and R.J. Stevenson, U.S. Patent 7064117(2006).

14. N. Muruganantham, R. Sivakumar, N. Anbalagan, V. Gunasekaran and J.T. Leonard, Biol. Pharm. Bull., 27, 1683 (2004).
15. M.P. Maguire, K.R. Sheets, K. McVety, A.P. Spada and A. Zilberstein, J. Med. Chem., 37, 2129 (1994).

16. W.D. Wilson, M. Zhao, S.E. Patterson, R.L. Wydra, L. Janda and L. Strekowski, Med. Chem. Res., 2, 102 (1992).

17. L. Strekowski, J.L. Mokrosz, V.A. Honkan, A. Czarny, M.T. Cegla, R.L. Wydra, S.E. Patterson and R.F. Schinazi, J. Med. Chem., 34, 1739 (1991).

18. M. Gopal, S. Shenoy and L.S. Doddamani, J. Photochem. Photobiol. B, 72, 69 (2003).

19. Y.H. Kim, K.J. Shin, T.G. Lee, E. Kim, M.S. Lee, S.H. Ryu and P.G. Suh, Biochem. Pharmacol., 69, 1333 (2005).

20. Y.L. Zhao, Y.L. Chen, F.S. Chang and C.C. Tzeng, Eur. J. Med. Chem., 40, 792 (2005).

21. L.H. Hurley, Nat. Rev. Cancer, 2, 188 (2002).

22. M. Israel, L.C. Jones and E.J. Modest, J. Heterocycl. Chem., 9, 255 (1972).

23. B. Vigante, G. Tirzitis, D. Tirzite, B. Chekavichus, J. Uldrikis, A. Sobolev and G. Duburs, Chem. Heterocycl. Comp., 43, 225 (2007).

24. T. Utsugi, K. Aoyagi, T. Asao, S. Okazaki, Y. Aoyagi, M. Sano, K. Wierzba and Y. Yamada, Jpn. J. Cancer Res., 88, 992 (1997).

25. M. Manpadi, P.Y. Uglinskii, S.K. Rastogi, K.M. Cotter, Y.-S.C. Wong, L.A. Anderson, A.J. Ortega, S. Van slambrouck, W.F.A. Steelant, S. Rogelj, P. Tongwa, M.Y. Antipin, I.V. Magedov and A. Kornienko, Org. Biomol. Chem., 5, 3865 (2007).

26. R. Ghahremanzadeh, G. ImaniShakibaei, S. Ahadi and A. Bazgir, J. Comb. Chem., 12, 191 (2010).

27. F. Abbate, A. Casini, T. Owa, A. Scozzafava and C.T. Supuran, Bioorg. Med. Chem. Lett., 14, 217 (2004).

28. W.R. Chegwidden and S.J.I.M. Dodgson, Spencer. EXS, 90, 343 (2000).

29. S.M. Abdel-Gawad, M.S. A.El-Gaby, H.I. Heiba, H.M. Aly and M.M. Ghorab, J. Chil. Chem. Soc., 52, 1227 (2005).

30. M.M. Ghorab, M.S. Alsaid and E.M. El-Hossary, J. Heterocycl. Chem., 48, 563 (2011).

31. S.I. Alqasoumi, A.M. Al-Taweel, A.M. Alafeefy, E. Noaman and M.M. Ghorab, Eur. J. Med. Chem., 45, 738 (2010).

32. M.M. Ghorab, F.A. Ragab, S.I. Alqasoumi, A.M. Alafeefy and S.A. Aboulmagd, Eur. J. Med. Chem., 45, 171 (2010).

33. M.S. Al-Said, M.M. Ghorab and Y.M. Nissan, Chem. Cent. J., 6, 64 (2012).

34. M.M. Ghorab and M.S. Alsaid, Arch. Pharm. Res., 35, 987 (2012).

35. M.M. Ghorab and M.S. Alsaid, Arch. Pharm. Res., 35, 965 (2012).

36. M.M. Ghorab, M.S. Alsaid and Y.M. Nissan, Arzneimittelforschung. Drug Res., 62, 497 (2012).

37. Brucker, APEX2, SAINT and SADABS, Brucker AXS Inc., Madison, Wisconsin, USA (2009).

38. B. Liu, X.B. Chen, X.H. Yang, D.F. Pan and J.K. Ma, Acta Crystallogr, 66E, 02225 (2010).

39. Y.H. Jang, L.C. Sowers, T. Çagin and W.A. Goddard. J. Phys. Chem., 105, 274 (2001).

40. G.M. Sheldrick, Acta Crystallogr., 64A, 112 (2008)

41. A.L. Spek, Acta Crystallogr., 65D, 148 (2009).

42. R. Ferrer, G. Lobo, N. Gamboa, J. Rodrigues, C. Abramjuk, K. Jung, M. Lein and J.E. Charris, Sci. Pharm., 77, 725 (2009).

43. M.G. Priya, T. Srinivasan, K. Girija, N.R. Chandran and D. Velmurugan, Acta Crystallogr., 67E, 02310 (2011).

44. P. Skehan, R. Storeng, D. Scudiero, A. Monks, J. McMahon, D. Vistica, J.T. Warren, H. Bokesch, S. Kenney and M.R. Boyd, J. Natl. Cancer Inst., 82, 1107 (1990). 